\title{
核酸医薬を用いた 血管疾患に対する分子治療法
}

要約：分子生物学の進歩に伴い血管疾患の病態解明が 進み病変進行に関与する遺伝子・細胞内シグナルなど をターゲットにした分子治療も考案されてきた。その なかで核酸医薬を使った治療法の開発も行われ，多く の遺伝子制御法が研究されている。核酸医薬は目的と する $\mathrm{DNA} \cdot \mathrm{mRNA} の$ 相補的な塩基配列をもつ人工的 に化学合成された核酸分子で高い特異性と容易な合成 法が特徵である。動物実験で有用性が報告された主な ものはアンチセンスとデコイで，臨床試験に進んでい る研究もあり次世代の治療薬として期待されている. 対象疾患のひとつに血行再建後の内膜肥厚による再狭 窄がある。アンチセンス法では細胞周期調節遺伝子を ブロックして平滑筋細胞の増殖を抑制する方法がとら れ，デコイ法では多くの細胞周期遺伝子群を制御して いる転写因子 E2F の活性を抑制する治療法が検討さ れた。また病変進行に重要な因子である炎症を制御す る転写因子 $\mathrm{NF} \kappa \mathrm{B}$ に対するデコイも良好な内膜肥厚 抑制効果を報告している。 しかし E2F デコイの臨床 試験では有意な治療効果が見られず，さらに複数の現 象を制御するため $\mathrm{NF} \kappa \mathrm{B}$ と $\mathrm{E} 2 \mathrm{~F}$ を同時に抑制するキ メラデコイの開発が行われている。また小径の動脈瘤 もデコイ療法のターゲットとなっている．動脈瘤の進 展には血管壁の炎症と MMP の発現による細胞外又 トリックスの破壊が重要な機序になっている。これに 関与する転写因子が $\mathrm{NF} \kappa \mathrm{B}$ と ets であり，これをデ コイで同時に抑制することで動脈瘤の縮小効果が見ら れ，MMP 分泌・炎症の抑制による細胞外マトリック スの破壊停止に加え，エラスチン・コラーゲンの合成 抑制を解除し細胞外マトリックスを再生する効果が確 認された。このように核酸医薬は血管疾患においても 新規治療法となる可能性が示されている.

\section{1． 血管疾患に対する分子治療の現状}

血管疾患の分子治療は, 経皮的血管形成術や外科的 なバイパス術後に発生する再狭窄の予防をターゲット として研究が進んできた。 その主な方法として 1）遺 伝子導入により特定のタンパク質を発現させる，また は変異型タンパク質を発現させ正常タンパク質の機能 を抑制する遺伝子治療，2）中和抗体を投与して目的 タンパク質の機能を抑制する抗体療法，3）核酸医薬 による目的遺伝子・タンパク質の発現を制御する方法 などが考案されてきた。このなかには基礎的検討から 臨床治験を行っている研究もあり, 創薬に向けて今後 ますます進んでいく分野であると期待されている，本 稿では核酸医薬を使った血管疾患の治療法に関して紹 介するが，特に核酸医薬のなかでデコイ療法を使った 治療法について最近の著者らの知見を中心に概説する.

\section{2. 核酸医薬の作用機序}

核酸医薬は目的とする DNA・mRNAの相補的な塩 基配列をもつ人工的に化学合成された核酸分子である。 その構造はアンチセンスのように 1 本鎖のもの, デコ イや siRNAのように 2 本鎖のものがあり，その機序. 作用部位もそれぞれ異なっている. 動物実験で治療薬 として有効性を報告された方法はアンチセンス法，デ コイ法そしてアプタマーがあり，その他にも遺伝子機 能の解析などに応用されている方法もある（図 1).

\section{1）アンチセンス法}

アンチセンスは目的遺伝子の mRNA と特異的に結 合する核酸配列をもった合成核酸であり，これを細胞 内に導入し目的の遺伝子と 2 重鎖を形成させタンパク 質の発現を抑制する方法で目的以外の遺伝子には影響

キーワード：デコイ，アンチセンス，アプタマー, $\mathrm{NF} \kappa \mathrm{B}, \mathrm{E} 2 \mathrm{~F}$

大阪大学 大学院医学系研究科 臨床遺伝子治療学（テ565-0871 吹田市山田丘 2-2)

e-mail: miyake@cgt.med.osaka-u.ac.jp 原稿受領日：2006 年 11 月 21 日，会誌編集委員会依頼原稿

Title: Molecular therapy for vascular disease using an oligonucleotide-based strategy

Author: Takashi Miyake, Ryuichi Morishita 


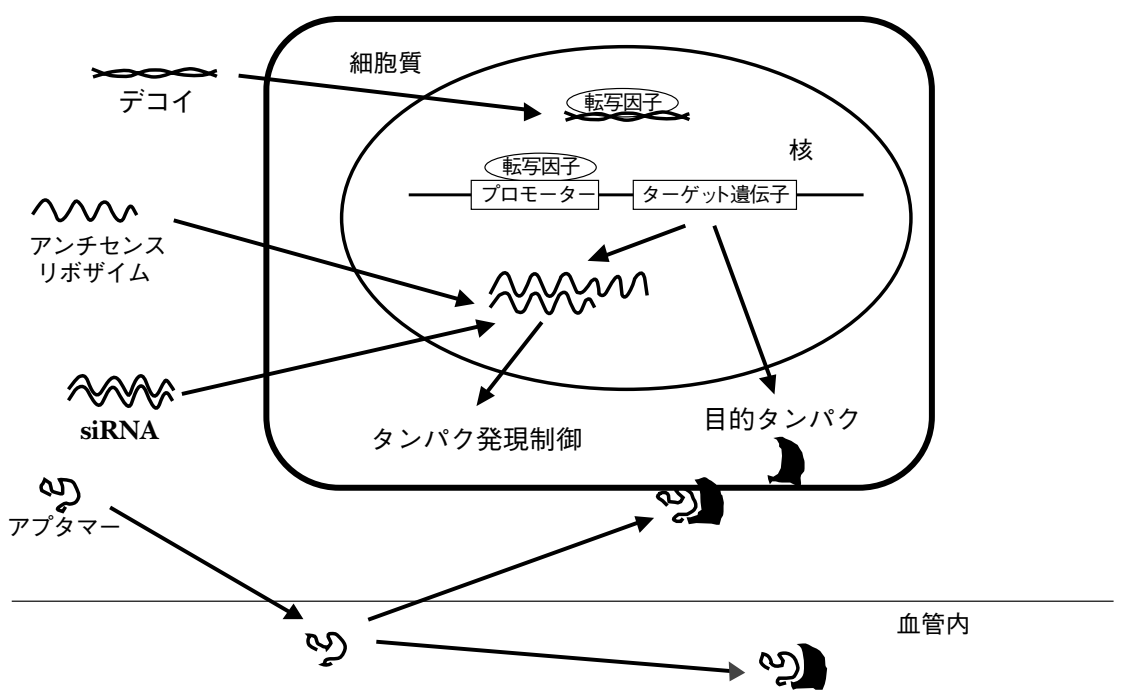

図 1 核酸医薬の作用部位・機序

(Morishita R. J Pharmacol Sci. 2004;95:1-8. より改変引用)

を及ぼすことはない。

\section{2) siRNA (short-interfering RNA)}

RNA 干渉（RNA interference）は目的とする遺伝子 と相同な二本鎖 RNA が標的遺伝子の転写産物 （mRNA）の相同部分の分解を促進し，タンパク質の 発現を特異的に抑制する現象である。この現象を利用 して人工的に合成された $21 \sim 25$ 塩基の二本鎖 RNA を導入することでタンパク発現を抑制する方法が siRNA 法である. 現在は主に遺伝子の機能解析に利用さ れているが，治療方法としても期待されている.

3）アプタマー

核酸ライブラリーから人工的に得られる一本鎖核酸 分子で，抗体と同じょうに目的とするタンパク・低分 子化合物と結合して機能を阻害することができる．高 い親和性と特異性をもっており，合成も容易で阻害薬 の合成も可能である.

\section{4) デコイ}

さまざまな刺激により一連の遺伝子群が発現または 抑制される初期の過程には特定の転写調節因子が関与 している.デコイ療法はこの転写因子をブロックする ことで活性化される遺伝子群の発現を調節する方法で ある．転写因子の結合部位を含むオリゴヌクレオチド を合成・二重鎖核酸（デコイ）とし，ターゲット細胞 の核内に導入する。このデコイが転写因子と結合する ことで DNA 上への転写因子の結合を阻害してプロモ ーター活性が低下, 本来発現する遺伝子群がコントロ ールされる。このデコイ療法は細胞周期や炎症など夕 ーゲットとなる現象に関与する複数の遺伝子を同時に
制御することが可能であり，一般にアンチセンス法よ り高い効果を得ることができる（図 2）。

\section{3. 血行再建後の再狭窄予防}

心冠状動脈や末梢動脈の動脈硬化による狭窄病変に ステント留置などの経皮的血管形成術が行われている が $30 \sim 40 \%$ に再狭窄が起こり, 静脈グラフトを使っ た外科的血行再建術でも 15 年で $40 \sim 50 \%$ の狭窄 . 晚期閉塞が起こる。これらの再狭窄は動脈硬化の進行 に加えて, 手技に伴う内皮障害やマクロファージの浸 潤など炎症反応の発生に続く中膜平滑筋細胞の内膜へ の遊走・増殖そして細胞外器質の沈着による新生内膜 肥厚が原因と考えられている，ステント留置術では平 滑筋細胞の増殖を薬剂で抑える薬郕溶出性ステントが 開発され急性期の再狭窄は改善されたが, 内膜再生の 遅延による血栓形成や長期成績が問題点として残って いる．核酸医薬の分野でも新生内膜肥厚の進展に関係 する因子を制御する治療方法が考案された。

\section{1）細胞周期をコントロールするアンチセンス法}

平滑筋細胞が増殖するためには細胞周期の進展が必 要であり, これは細胞周期調節遺伝子群でコントロー ルされている。これらの遺伝子群には c-myc, c-myb, cdc2, PCNA そしてチミジンキナーゼなどが含まれて いる. アンチセンス法を用いてこれらの遺伝子群の発 現を抑制し, 細胞周期を停止させ平滑筋細胞の増殖を 抑制する治療法が考案された。1992 年に前発癌遺伝 子でもある c-myb に対するアンチセンスが再狭窄予 防に有効であった報告がされた (1). その後 c-mycア 
未刺激時
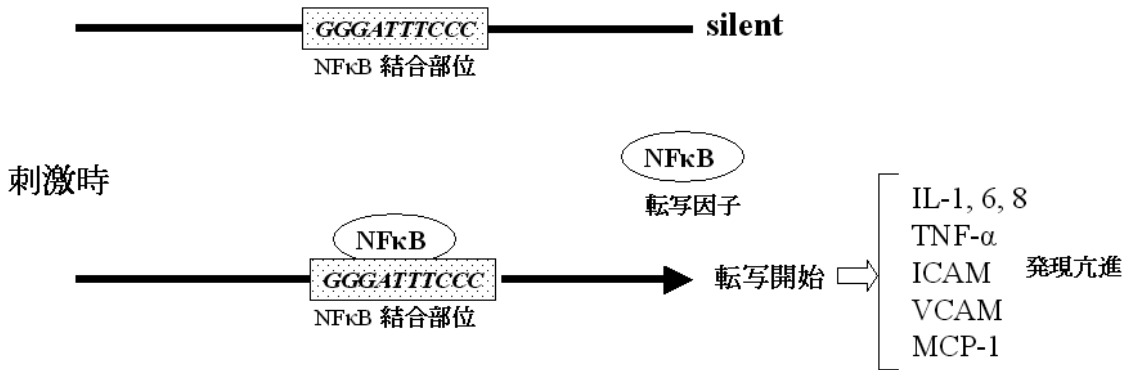

デコイ導入時

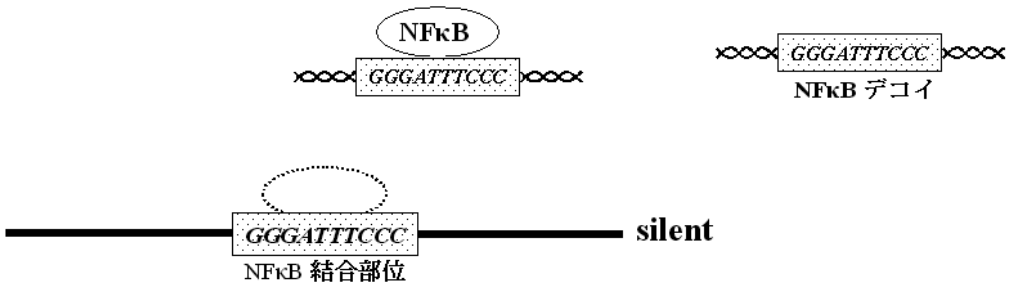

図 $2 N F \kappa B$ デコイのストラテジー(文献 17 より改变)

ンチセンスの内膜肥厚に対する有効性も動物モデルで 証明され，最近 c-mycに対するアンチセンスを用い 再狭窄の予防を目的とする臨床試験が報告された。内 膜肥厚，再狭窄率に有意な差は見られなかったが，べ クターを使わずにアンチセンスを冠動脈内投与する方 法で低い導入効率が原因と考えられている(2).われ われも細胞周期調節因子である PCNA と cdc2 キナー ゼを同時に抑制するアンチセンスの導入が内膜肥厚を 抑制することを報告した(3)。その他にも増殖因子で ある PDGFをターゲットにしたアンチセンスの有効 性も報告されている.

\section{2）增殖因子を抑制するアプタマー法}

VEGFに結合するアプタマーは，成人に失明をきた す加齢黄班変性症の治療薬としてすでに製品化されて いる. 血管疾患では内膜肥厚の抑制に PDGF-B に対 するアプタマーの動物実験が報告された。この報告で は短期間の抑制効果は認めたが, 6 週後の長期での抑 制効果は消失しており投与期間・他剂併用の必要性を 述べている(4)．血管疾患をターゲットにしたアプタ マーの報告は少なく問題点もあるが，標的分子の多様 性もあり今後研究が進んでいく分野と考えられている.

\section{3）細胞周期・焱症を制御するデコイ法}

アンチセンス法でターゲットにした細胞周期調節遺 伝子群のプロモーター部位に転写因子 E2F の結合部 位があり，これらの発現をコントロールしている。 $\mathrm{E} 2 \mathrm{~F}$ は細胞周期の静止期では不活性化されて Rb (Reti- noblastoma）と結合しており, 刺激時に Rb から遊離・ 活性化され $\mathrm{S}$ 期進展に必要な細胞周期調節遺伝子群 の上流にある転写因子結合配列に結合し遺伝子群を発 現させ細胞増殖をひき抏こす，我々は E2Fに対する デコイを平滑筋細胞に導入することで平滑筋細胞の増 殖を抑え内膜肥厚が抑制できると考え，ラットの頚動 脈バルーン障害モデルや豚の冠状動脈バルーン障害モ デルで内膜肥厚の抑制を報告した(5)。一方，米国で は $\mathrm{E} 2 \mathrm{~F}$ デコイ療法による静脈グラフトの再狭窄予防 を目的とした臨床試験が行われた。フェーズ I・II の 試験では安全性・有効性が確認され, その良好な結果 からフェーズ III の臨床治験が実施された。この試験 では心臓，下肢の外科的な血行再建術で使用する静脈 グラフトに $\mathrm{E} 2 \mathrm{~F}$ デコイを術中導入するデザインであ ったが，対象群に比べ再狭窄率の低下は見られなかっ た $(6,7)$. しかしこの報告からいくつかの問題点が明 らかになった。その一つに内膜肥厚は多因子の関与で 進展していくため細胞増殖のコントロールだけでは十 分な効果が得られないことである. 血管壁の炎症も内 膜肥厚に関与する重要な因子と考えられており, イン ターロイキン-1,2,6,8 などのサイトカイン, MCP-1 な どのケモカイン, ICAM,VCAM といった接着因子の 発現立進が動脈硬化巣でみられており炎症細胞の浸潤 を誘導する (8)。これらの炎症関連因子の遺伝子発現 を制御する転写因子に $\mathrm{NF} \kappa \mathrm{B}$ がある。人間の動脈硬 化部位で $\mathrm{NF} \kappa \mathrm{B}$ の活性立進が報告されており, 我々 
は $\mathrm{NF} \kappa \mathrm{B}$ を抑制するデコイは $\mathrm{E} 2 \mathrm{~F}$ デコイと異なるア プローチとして内膜肥厚の抑制に有効と考えた。こう して新規合成した $\mathrm{NF} \kappa \mathrm{B}$ デコイはラットやブタの動 脈バルーン障害モデルで内膜肥厚の著明な抑制効果を 認めた(8).さらにウサギ静脈グラフトモデルでは内 膜肥厚の抑制に加え, 中膜の肥厚を誘導し動脈系にお ける静脈グラフトの早期安定化を認めている。また $\mathrm{NF} \kappa \mathrm{B}$ デコイには内皮細胞の保護効果が培養実験で 報告されており, 静脈グラフトでも内皮依存性の血管 拡張作用の改善を認めている(9).

以上のように $\mathrm{E} 2 \mathrm{~F}$ と $\mathrm{NF} \kappa \mathrm{B}$ は内膜肥厚の進展に異 なる機序で関与している。 そこでこれら 2 つの転写因 子の DNA 結合を阻害するために，それぞれの結合モ チーフを合わせ持つキメラデコイを作製し，その効果 をウサギ人工血管移植モデルで検討した. キメラデコ イは平滑筋細胞増殖と炎症反応の両者を抑制し吻合部 内膜肥厚の進展を抑えた。米国で行われた E2Fデコ イの試験では十分な効果が得られなかったが, 新たな アプローチとしてキメラデコイの臨床での有効性に期 待がもたれる。

\section{4. 核酸医薬による動脈瘤治療}

動脈瘤は無症候性に発症・増大して最終的に破裂を きたし死に至る疾患である。破裂の予防目的で外科的 な人工血管置換術が行われ良好な治療成績をあげてお り, 最近ではより低侵襲なステントグラフト留置術が 開発された。これらの治療法は破裂の危険性が高い瘤 径 $4.5 \mathrm{~cm}$ 以上が一般的な適応となっている. しかし 近年 CT や超音波検查が日常診療や検診で行われるよ うになり，小径の動脈瘤が発見されることも多くなっ た。 小径瘤は破裂の危険が少ないため経過観察となる が，自然に退縮する事はなく増大した時点で侵襲の大 きい外科的治療が行われている. しかし小径瘤は薬物 や分子治療に反応する多くの細胞を血管壁内に含有し ているので, 早期に発見されたメリットを生かす低侵 襲性の新しい治療法の確立が期待されている.

\section{1） $\mathbf{N F} \kappa \mathbf{B} \cdot$ ets $の$ 動脈瘤への関与}

動脈瘤の発症・進展には血管壁外膜側の炎症と matrix metalloproteinases (MMP) の発現立進による細 胞外マトリックス, 特に弾性繊維の破壊が重要な機序 になっている．我々はこれらの病態に関与する転写因 子として $\mathrm{NF} \kappa \mathrm{B}$ と etsに注目した。 $\mathrm{NF} \kappa \mathrm{B}$ は炎症に 関与する転写因子であることは前述したが，動脈瘤の 病理所見では外膜側の炎症細胞の浸潤が認められてお り,この炎症細胞が平滑筋細胞と共に多種の MMP を 分泌し血管壁の破壊を引き起こすと考えられている.
また $\mathrm{NF} \kappa \mathrm{B}$ は $\mathrm{MMP}$ 遺伝子群のプロモーター部分に 結合部分があり直接 MMP-1, MMP-2, MMP-3 そし て MMP-9 の合成を充進する(10-12).また ets は造血, 血管発生に関与する遺伝子群をコントロールする転写 因子であるが，これも直接 MMP のプロモーターに結 合部位を持ち MMP-1, MMP-2 そして MMP-9 の発 現を立進することが明らかにされている(13-16).我々 の検討でも動脈瘤症例の術中に得られた瘤壁サンプル の検討で $\mathrm{NF} \kappa \mathrm{B}$ と ets の発現立進を確認しており, 特に拡張が進行中である頸部で強い活性を認めている.

\section{2）キメラデコイの動脈瘤治療効果}

病理検討から $\mathrm{NF} \kappa \mathrm{B}$ と ets を同時に抑制すること は血管壁の炎症と複数の夕イプの MMP 発現を抑え ることが可能で動脈瘤の有効な治療方針になると考え られた。これまでにも抗炎症薬や MMP 阻害薬を使っ た動脈瘤モデルでの拡大予防効果が報告されている. 我々はこれら 2 つの転写因子に結合し活性を抑制する キメラデコイを作製した。手術中に得られた瘤壁サン プルを使った組織培養ではキメラデコイは用量依存性 にMMP-1 と MMP-9 の分泌を抑制した。この結果を もとにラットとウサギの動脈瘤モデルでキメラデコイ の有効性を検討した(17). 我々はセルロースを基材に したデコイ導入シートを作製し，これを血管周囲に巻 くことで動脈瘤の主病変である外膜側から中膜の一部 まで導入可能な方法を考案した。ウサギの実験では動 脈瘤壁にキメラデコイを導入することで，接着因子 VCAM-1 とケモカイン MCP-1 の発現を抑えてマクロ ファージの浸潤を抑制した。さらに瘤の進展に重要な MMP-2 と MMP-9 の活性抑制をデコイ治療群で確認 した。この結果キメラデコイは弾性繊維の破壊を抑制 することで動脈瘤拡大に対する予防効果を示した（図 3)。しかし臨床応用をするためには完成された動脈瘤 に治療効果を示す必要がある。そこで動脈瘤作成の 1 週間後にデコイを導入する実験を行い動脈瘤の縮小効 果をみとめた。そのメカニズムは予防効果の実験と同 様に MMP 分泌・炎症の抑制による細胞外マトリック スの進行する破壊の停止であり, さらに $\mathrm{NF} \kappa \mathrm{B}$ と ets の活性は血管壁の構成成分であるエラスチン，コラー ゲンの合成抑制に働くが，キメラデコイはこの抑制を 解除し弾性繊維・コラーゲン繊維の合成による瘤壁再 生の効果も認めている。このように $\mathrm{NF} \kappa \mathrm{B}$ と ets に 対するデコイ療法は動脈瘤の早期治療となる可能性が 示された.

\section{5. 今後の核酸医薬を用いた治療法}

核酸医薬は次世代の治療薬として期待されており, 
a)
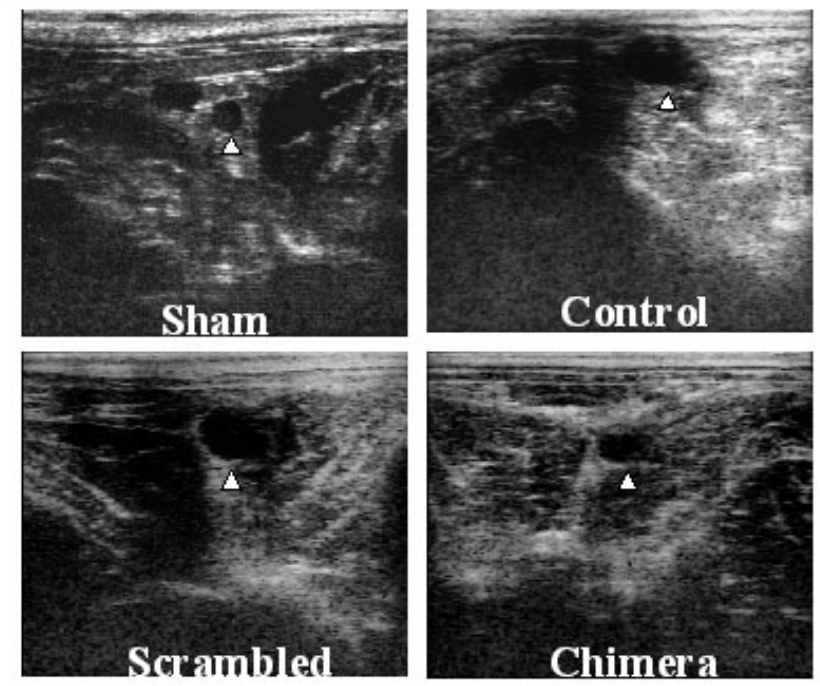

b)
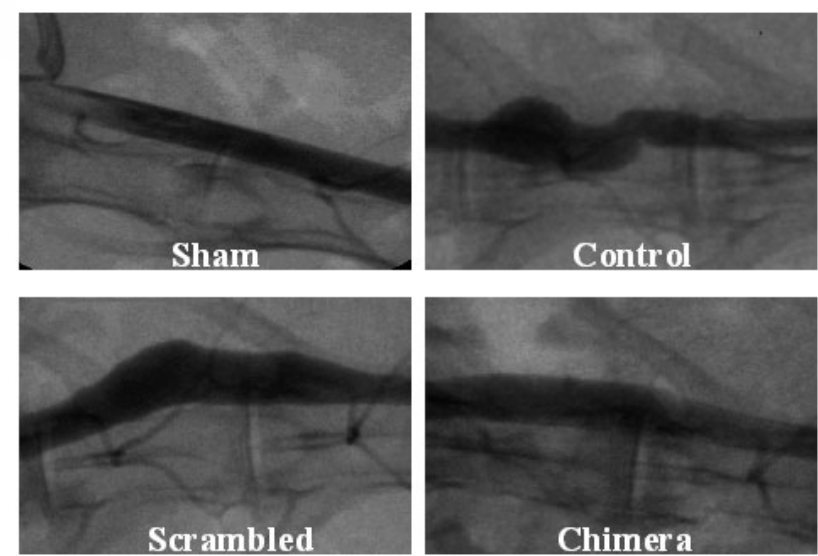

c)

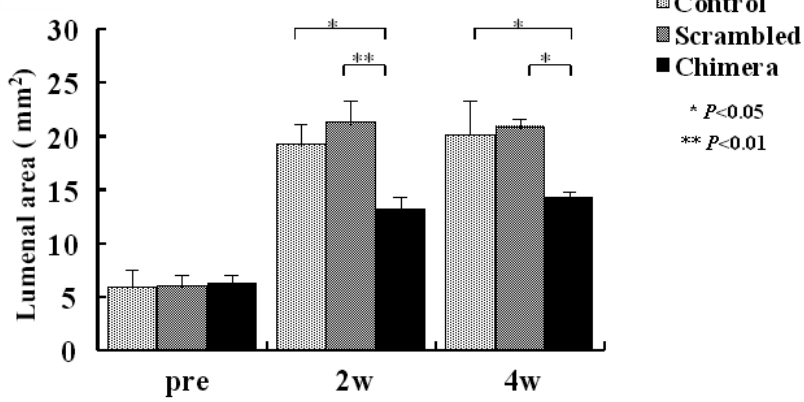

図 3 ウサギ動脈瘤におけるキメラデコイの進展予防効果 a）超音波画像，b）血管造影，C）超音波を使った瘤径の比較. キメラデコイは有意に動脈瘤の拡張を抑制した，Control: 対象群， Scrambled : ランダム配列のデコイ投与群, Chimera : キメラ デコイ治療群。(文献 17 より改变)
新たな制御方法の開発も進んでいる。また病態解明が 進み新規の夕ーゲット遺伝子・タンパクの探索も行わ れている。しかし血管疾患に対する治療法は基本的に 局所療法と考えられているので，その導入方法と効率 が問題点となってくる. 外科治療に取り入れる場合は 体外で導入することが可能で有効な手段であるが，経 皮的血管形成術ではバルーンを使った導入になるので 導入効率の低下が䀣念されている。また動脈瘤の治療 で我々が行ったデコイシートによる導入は, 病変の首 座である外膜側に作用させる局所療法であるが，瘤周 囲の剥離が必要であり侵襲的な治療法であることに変 わりはない。より効果的で安全な遺伝子導入法・デリ バリーシステムの確立が急務であり, さらに静脈投与 で選択的に動脈硬化部位などの目的血管へ導入できる ような組織特異的導入法が開発できれば，核酸医薬は 日常診療で使える治療薬として確立される。

\section{文献}

1) Simons M, et al. Nature. 1992;359:67-70.

2) Kutryk MJ, et al. J Am Coll Cardiol. 2002;39:287-287.

3) Morishita R, et al. Proc Natl Acad Sci U S A. 1993;90:84748478.

4) Leppanen O, et al. Arterioscler Thromb Vasc Biol. 2000;20: E89-95.

5) Nakamura T, et al. Gene Ther. 2002:9:488-494.

6) Alexander JH, et al. JAMA. 2005;294:2446-2454.

7) Conte MS, et al. J Vasc Surg. 2006;43:742-751.

8) Yamasaki K, et al. Gene Ther. 2003;10:356-364.

9) Miyake T, et al. J Mol Cell Cardiol. 2006;41:431-440.

10) Bond M, et al. Biochem Biophys Res Commun. 1999;264:561567.

11) Takeshita H, et al. J Virol. 1999;73:5548-5555.

12) Kim H, et al. Biochem Biophys Res Commun. 2000;269:401405

13) Vandenbunder B, et al. Folia Biol (Praha). 1994;40:301-313.

14) Nerlov C, et al. Oncogene. 1991;6:1583-1592.

15) Gum R, et al. J Biol Chem. 1996;271:10672-10680.

16) Watabe T, et al. Int J Cancer. 1998;77:128-137.

17) Miyake T, et al. Gene Ther. 2006;13:695-704.

著者プロフィール

\section{三宅隆（みやけ たかし）}

大阪大学 大学院医学系研究科 臨床遺伝子治療学, 特任研究員, 医学博士.

$\diamond 1987$ 年川崎医科大学卒業, ’89 年川崎医科大学 胸部心臓血 管外科教室 入局, ’ 90 年川崎医科大学 大学院, ’02 年大阪大 学 遺伝子治療学, ’03 年大阪大学 臨床遺伝子治療学.

$\diamond$ 研究テーマ: 心臟血管外科, 遺伝子治療. 趣味 : カヌー. 